\title{
THE AUTOMOBILE CLUBS AND THE COURTS
}

\author{
EDWARd B. BullBiT*
}

Until fairly recently it had apparently been the general practice of motor clubs to furnish their members with certain services of a legal nature in connection with their "memberships" or contracts. ${ }^{1}$ Since I931 a number of cases have arisen in which it has been charged that the automobile clubs in rendering these services are engaged in the unauthorized practice of law. ${ }^{2}$ In all of the cases which have been brought to the courts of last resort - except in one instance ${ }^{3}$ - this charge has been sustained ${ }^{4}$ against the motor clubs. Usually no emphasis has been placed upon any particular type of service rendered by the clubs, but the courts have simply found that the practices as a whole constituted unauthorized practice of law. On this account it has been deemed unnecessary to deal separately with the specific services rendered by each motor club in the discussion of the individual decisions. All of the clubs involved in these cases had been providing for defense of members in magistrate and police courts for minor charges under the motor vehicle laws, and some even handled more serious charges, such as manslaughter. Most of them also were prepared to give legal advice to their members on matters with reference to the use or ownership of their automobiles, and to defend property damage suits brought against members as a result of collisions. Some had provisions for defense of personal injury claims and for prosecution of civil claims, and at least one provided for prosecution of criminal charges on behalf of members in courts without regular prosecuting attorneys. ${ }^{5}$

-A.B., 1935, Gettysburg College. Now a member of the third year class in the Duke University Law School. Member of the Editorial Board, Duke Bar Association Journal.

${ }^{1}$ Results of private investigation indicate that these practices are being continued, apparently without active disapproval on the part of the bar, in at least a few of the states whose courts have not considered the question.

2 People ex rel. Chicago Bar Association v. Motorists' Association of Illinois, 354 Ill. 595, I88 N. E. 827 (1933); People ex rel. Chicago Bar Association v. Chicago Motor Club, 362 Ill. 50, 199 N. E. I (1935); In re Maclub of America, 3 N. E. (2d) 272 (Mass. 1936); In re Thibodeau, 3 N. E. (2d) 749 (Mass. 1936); State ex rel. Seawell v. Carolina Motor Club, 209 N. C. 624,184 S. E. 540 (1936); Rhode Island Bar Association v. Automobile Service Association, 55 R. I. 122, I79 Atl. I39 (1935); Yeats v. Automobile Owaers Association of Florida, Brand, Unauthorized Practice Decisions (1937) 326 (C. C. Fla. I934); Schuur v. Detroit Automobile Club, id. at 698 (C. C. Mich. 1937); Goodman v. Motorists' Alliance, 29 Ohio N. P. (N. S.) 3 I (C. P. 193I); Dworken v. Cleveland Auto Club, 29 Ohio N. P. (N. S.) 607 (C. P. 1931).

${ }^{3}$ In re Thibodeau, stupra note 2.

'Several cases have arisen also in the lower courts of Ohio (Goodman v. Motorists' Alliance, and Dworken v. Cleveland Auto Club, both supra note 2), and one in a Florida lower court (Yeats v. Automobile Owners Association of Florida, supra note 2), in all of which injunctions werc granted against incorporated motor clubs which were furnishing legal services.

-State ex rel. Seawell v. Carolina Motor Club, supra note 2. 
In only one $\operatorname{case}^{6}$ has there been any indication that a motor club has performed legal services through other than duly licensed attorneys. In most of the other cases, the courts have said that these clubs could not perform legal services themselves because not licensed to practice law, and that they could not be permitted to accomplish indirectly, through the hiring of attorneys, what they could not legally do directly. The clubs' activity in this regard has been characterized by some courts as the buying and selling of legal services. The underlying objection seems to be that the intervention of a lay intermediary, whom the attorney regards as the source of both his employment and remuneration, destroys the relation of trust and confidence between attorney and client which has traditionally been regarded as necessary. ${ }^{7}$ A practical objection is that these clubs, in effect, solicit business for the attorneys associated with them and employ commercial methods which attorneys in private practice are not permitted to use. ${ }^{8}$

On behalf of the motor clubs it has been urged that most of the cases handled by them are small cases which would never be taken care of if the individual were forced to bear the entire burden of the litigation on his own shoulders, and that a plan whereby those with common interests join together for mutual protection and assertion of their rights is the only practical method of seeing justice done in this situation. ${ }^{9}$ Another theory of defense which the clubs have advanced is that taking the individual's case is merely incidental to the fulfilling of the purpose of the club to protect and foster the interests of motorists as a whole. ${ }^{10}$

While some of the cases have been decided under statutes forbidding corporate practice of law, ${ }^{11}$ it has been found unimportant that the club was a voluntary association andi not a corporation in one case, ${ }^{12}$ and no significance was attached to the fact that the association involved in another case ${ }^{13}$ was really a business conducted by an individual attorney even though the court there decided in favor of the club and was seeking to distinguish other cases. Hence, it is probable that the form of organization which the club takes is not a determining factor, although the existence of the corporate form makes available to the courts the well-established principle that a corporation cannot practice law. ${ }^{14}$

'Ibid. Lay members of the club had written letters on club stationery, demanding payment of damages for injuries claimed to have been caused by the negligent operation of the automobile by the other party involved, and follow-up letters were sent out by the club-the lower court found as a fact that the defendants by this practice were expressing and giving an opinion, at least indirectly, by adopting or confirming the opinion of the club member as to negligence as a matter of law on the part of the claimee, and as to the proper amount of damages involved in a case of tort liability. The court did not so indicate but it is probable that its finding was with reference to the follow-up letters only.

${ }^{7}$ In re Co-operative Law Co., 198 N. Y. 479, 92 N. E. 15 (1910). Comment (1937) Io So. Calif. L. REv. 329.

${ }^{3}$ Aas. Bar Ass'n, Canons of Professional Ethics (r937), Canon 27, p. 16.

${ }^{\circ}$ Comment (1934) 2 U. of CHr. L. Rev. IIg.

${ }^{10}$ People ex rel. Chicago Bar Association v. Chicago Motor Club, State ex rel. Seawell v. Carolina Motor Club, Schuur v. Detroit Automobile Club, all supra note 2.

${ }^{2}$ People ex rel. Chicago Bar Association v. Motorists' Association of Illinois, In re Maclub of America, State ex rel. Seawell v. Carolina Motor Club, all supra note 2.

${ }^{22}$ Rhode Island Bar Association v. Automobile Service Association, supra note 2.

${ }^{23}$ In re Thibodeau, supra note 2.

${ }^{13}$ Notes (1931) 73 A. L. R. 1327, (1936) I05 A. L. R. 1364. 
The highest court of Illinois has handed down two decisions within recent years, in both of which incorporated motor clubs were found in contempt and fined for performing legal services for members. In People v. Motorists' Association of Illinois, ${ }^{15}$ the association had urged that it was a non-profit corporation and therefore within the section of the Illinois statute ${ }^{16}$ which exempted corporations organized not for pecuniary profit from the operation of the statute enacted to prohibit corporations from practicing law. ${ }^{17}$ By way of an answer to this contention, the court pointed out that the same section which provided for the exemption also stated that no corporation should be permitted to render any services which could not lawfully be rendered by a person not admitted to practice law in the state, nor to solicit directly or indirectly professional employment for a lawyer. ${ }^{18}$ The court also relied upon its holding in a previous case ${ }^{\mathbf{1 0}}$ that a corporation could not be licensed by the legislature to practice law and that this rule applied to corporations organized not for profit. $^{20}$

In People ex rel. Chicago Bar Ass'n v. Chicago Motor Club,21 the same court stated that it was unable to condone the advertisements and solicitation of members by the club and the latter's admission that it was only acting as agent in rendering legal services for its members without abandoning precedents established in recent cases dealing with unauthorized practice. Again, the fact that the club was a corporation organized not for profit was not permitted to vary the rule that a corporation could neither practice law nor hire lawyers to carry on the business of practicing law for it. The court felt that public welfare demanded that legal services should not be commercialized and that "no corporation, association, or partnership of laymen can contract with its members to supply them with legal services, as if that service were a commodity which could be advertised, bought, sold, and delivered." It is interesting to note one contention advanced by the club as a part of its defense, namely, that its legal department had been approved by the Chicago Bar Association and excepted from the operation of its canons of ethics of 1928 , but that an amendment in $193 \mathrm{r}$ withdrew the sanction although the charter of the club and the extent of its activities remained the same. No reference was made to this ground of defense in the opinion.

The contention of the voluntary association in Rhode Island Bar Association v. Automobile Service Association ${ }^{22}$ that it had not violated a Rhode Island statute forbidding a person not admitted to practice from advertising or holding himself out as an attorney in certain ways ${ }^{23}$ was met by the court's finding that the act did not define for all purposes the practice of the law and further that if it had done so it would not impair or restrict the power of the Supreme Court over the practice of

\footnotetext{
${ }^{15}$ Supra note 2.

${ }^{10}$ ILL. REv. Stat. (Smith-Hurd, 1933) c. 32, $\$ 415$.

${ }^{17} I d . \$ 41 \mathrm{I}$.

${ }^{18}$ This provision would seem to render the exemption of nd practical effect as applied to corporations organized not for pecuniary profit.

${ }^{13}$ People ex rel. Courtney v. Association of Real Estate Taxpayers, 354 Ill. 102, 187 N. E. 823 (1933).

${ }^{20}$ It has been urged that a distinction should be made between pecuniary corporations which go into the law business on the one hand, and the banding together of individuals in voluntary, non-pecuniary associations to provide for themselves certain legal services on the other. See Comment, supra note 9.

21 Supra note 2.

$\Rightarrow$ R. I. Gen. Laws (1923) c. $401, \$ 44$.
} 
law. ${ }^{24}$ Adopting a broad view of practice of law, the court found that the acts performed by the association through counsel designated by it constituted such practice, and that the association with a duly licensed member of the bar would not absolve the members of the association from responsibility. The court stated that the respondents could not be allowed to do indirectly what they could not legally do directly, and thus evade the requirements of high standards for attorneys which the court had ordained as prerequisite to admission to the bar in order that the people might be assured the best possible service in the dispatch of their legal business.

The Supreme Court of North Carolina in State ex rel. Seawell v. Carolina Motor $C l u b^{25}$ granted injunctions against two corporations, the American Automobile Association and its affiliate, the Carolina Motor Club, on the grounds that the acts and methods of business of the defendants constituted violations of the North Carolina statute prohibiting the practice of law by any corporation, person, or association except licensed attorneys. ${ }^{26}$ The court sustained the right of the legislature, within constitutional limits, to prescribe the qualifications and establish the rules and regulations under which citizens may enter the practice of law. Because the right to practice law was regarded as a personal right of an individual, it was found that a corporation could not lawfully practice law and was therefore forbidden also from accomplishing the same thing indirectly by employing lawyers to practice for it. The club had been engaged in collecting claims for damages for members in addition to rendering legal services in connection with the defense of members in cases of motor code violations, and this was likewise condemned. ${ }^{27}$

Massachusetts is the only jurisdiction in which there have been cases affording an opportunity to draw the line between what will be permitted and what will not be permitted in the field of legal services on the part of automobile clubs. Massachusetts has a statute which forbids corporations practicing law for other than themselves or holding themselves out as being entitled to practice law or give legal advice in matters not relating to their lawful business. ${ }^{28}$ In the case of In re Maclub of America, ${ }^{29}$ a decree was entered against the respondent, a corporation, on the grounds that many of the contractual duties entailed in the "memberships" could be performed only by members of the bar in the practice of their profession, and that, after the intervention of this lay intermediary, the feeling of obligation on the part of attorneys would run not toward the individual members but toward the club which furnished the consideration, thus destroying the confidential and fiduciary relation of attorney and client. It was noted that the contract was one to furnish legal defense and not one to pay for legal defense undertaken by members. The court called attention to the fact that the commercial methods of advertising employed were contrary to standards required of members of the bar, and that the publication of a list of recommended

${ }^{24}$ See also In re Opinion of the Justices, 289 Mass. 607, 194 N. E. 313 (x935).

$\approx$ Supra note 2.

${ }^{23}$ N. C. CODE (Michie, r935) $\$ 199$ (a). $\quad{ }^{27}$ Supra note 6.

${ }^{3}$ Mass. Acts 1935, c. 346 , $\$$. For the attitude of the Massachusetts Courts on the question of the inability of the legislature to permit practice of law by corporations, sce In re Opinion of the Justices, supra note 24.

${ }^{20}$ Supra note 2. 
attorneys was in substance a representation that the club dealt wholesale in legal services.

The respondent in the case of In re Thibodeau, ${ }^{30}$ also a Massachusetts case, was a practicing attorney, a member of a Boston law firm, who operated the "Automobile Legal Association" as a sideline. Although this so-called association offered much the same services as the Maclub and employed commercial methods of advertising in order to solicit members, the court distinguished the two cases and held that there was no illegal practice of law in this instance. It is significant that neither this association nor the Maclub would institute proceedings on behalf of members. Provision was made only for defense of charges of automobile law violations, defense in civil suits, and advice. The Automobile Legal Association further restricted its liability in the case of civil suits to the defense of property damage suits and had no provision for defending personal injury suits. In a summary of benefits appearing in its magazine, the association had expressly stated that members were not obliged to call upon the listed attorneys, but might call on any attorney of their own choice. In the latter event there was a stipulation as to the extent for which the association would be liable for specific types of legal services rendered. ${ }^{31}$ Members were urged in this prospectus to communicate directly with attorneys in order that the confidential relation of attorney and client might exist from the start. ${ }^{32}$

The court, in distinguishing the Thibodeau case from the Maclub case which it had decided previously, stated that the Maclub was bound by contract to furnish legal defense, that it sold legal services, that it had control over the attorneys who did the work, and that members were its agents in employing attorneys; while the Automobile Legal Association performed none of the legal services and did not employ the lawyers who did the.work or intervene in any way to direct or control them, but simply paid the bills presented by these lawyers. These distinctions seem at best tenuous in the light of the finding by the court below in the Maclub case that members were at liberty to employ attorneys other than those listed (although urged to employ those on the list), and that when an attorney was retained by a member the Maclub knew nothing of it until the bill for services was presented by the attorney for the member, and did not take any part in the management of the case. Perhaps the distinctions between the two cases indicate a conflict between the desire to preserve the attorney-client relationship from commercialization, and the recognition that the individual will, in many small cases, be deprived of the benefits of legal services if he is forced to rely solely on his own resources.

The arrangement illustrated by $I n$ re Thibodeau would seem to approach a contract of insurance, which has been defined as any contract by which one of the parties

${ }^{\infty}$ Supra notc 2.

${ }^{31}$ Liability limited to $\$$ ro for advice, $\$ 25$ for defense for traffic violations, $\$ 35$ for defense in reckless driving cases, $\$ 50$ for defense of property damage suits, and $\$ 200$ for defense of manslaughter charges-it did not appear that there were any limits fixed where listed attorneys were employed.

${ }^{33}$ In discussing the propricty of an attorney engaging in such an enterprise the court stated that, while advertising such as was disclosed here would be grossly improper if for the lawyer himself, yet a member of the bar is free to engage in commercial pursuits of an honorable character and to advertise his purcly mercantile business honestly and fairly by ordinary commercial methods. 
for a valuable consideration, known as a premium, assumes a risk of loss or liability that rests upon the other, pursuant to a plan for the distribution of such risk..$^{33}$ A Kentucky case ${ }^{34}$ has held that a contract for defense of criminal and civil suits and prosecution of civil suits growing out of the use of an automobile is a contract of insurance. The court said that it could not distinguish the case from one where the contractee was paid and he in turn paid the attorney engaged to represent him. In Minnesota, the Supreme Court has found ${ }^{35}$ that an agreement to defend a contract holder against civil or criminal litigation resulting from the use of his automobile is insurance on the grounds that rendition of services was as much compensation for loss from a stated event as would be the payment of money under a Minnesota statute defining insurance. ${ }^{36}$ In neither of these cases was the issue presented as to the validity of the contract from the viewpoint of unauthorized practice of law as both involved the question whether the corporations had to comply with the state insurance laws. ${ }^{37}$

In only one case, ${ }^{38}$ decided in a Michigan Circuit Court, has a motor club received recognition of a right to engage in furnishing legal services, through its own legal department, to its members. While the decision was placed largely on the construction of Michigan statutes, the result was reached in the face of a provision that no corporation should be permitted to render any service which cannot lawfully be rendered by a person not admitted to practice law in the state nor to solicit directly or indirectly professional employment for a lawyer. ${ }^{39}$ This statute provided that a corporation or voluntary association should not be prohibited from employing an attorney or attorneys in and about its own immediate affairs. The technique of the decision was to find that although the activities of the non-profit corporation constituted practice of law, the interest taken in the individual member's case was but incidental, and that the cases were undertaken for the ultimate bringing into fruition of the larger purposes of the organization-in other words the club was the real party in interest. The court said that such practices had so entered into the warp and woof of the complex business and professional life as to have ripened into a practical rule of construction as to what legal services might be permitted by one not an attorney.

\footnotetext{
${ }^{33}$ VANCE, INSURANCE (1930), p. 57. At page 60, the same author states that an attorney who, for a fixed annual retainer, agrees to care for such legal business as may arise in connection with his client's activities, does not make a contract of insurance. Compare State ex rel. Physicians' Defense Co. v. Laylin, 73 Ohio St. 90, 76 N. E. 567 (1905) and Vredenburgh v. Physicians' Defense Co., I26 Ill. App. 509 (1906) (holding contracts for defense of physicians from malpractice suits not to be insurance), with Physicians' Defense Co. v. Cooper, 999 Fed. 576 (C. C. A. 9 th, 1912) and Physicians' Defense Co. v. O'Brien, I00 Minn. 490, III N. W. 396 (1907) (holding the same type of contract to be insurance). See Comment, supra note 7 .

${ }^{3 s}$ Allin v. Motorist's Alliance, $234 \mathrm{Ky} .7 \mathrm{I}_{4}, 29 \mathrm{~S}$. W. (2d) 19 (I930).

${ }^{*}$ State v. Bean, I93 Minn. I13, 258 N. W. I8 (1934).

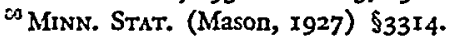

${ }^{3} \mathrm{~A}$ contention that the insurance company has a substantial interest in the suit such as would entitle it to conduct the defense would probably not be valid, since the obligation is merely to pay the attorneys' fees and is in no way dependent on the ultimate outcome of the suit.

${ }^{38}$ Schuur v. Detroit Automobile Club, supra note 2.

${ }^{30}$ MrCh. CoMp. Laws (1929) c. 197, \$ror75. This statute is substantially the same as the one in Illinois, supra note 16 .
} 
In one of its early opinions, ${ }^{40}$ the Committee on Professional Ethics and Grievances of the American Bar Association disapproved the furnishing of legal services by an automobile club to its members, irrespective of the method of retaining lawyers or whether the club was operated for profit. Canon 35 of the American Bar Association's Canons of Professional Ethics ${ }^{41}$ expressly provides that a lawyer may accept employment from an organization such as a club or trade association to render legal services in any matter in which the organization as an entity is interested, but this employment should not include the rendering of legal services to the members of such an organization in respect to their individual affairs. ${ }^{42}$ Charitable societies rendering aid to the indigent are not deemed intermediaries by the terms of this canon.

The problem presented with reference to automobile clubs has also arisen in connection with medical defense plans and various protective associations. The courts have usually refused to recognize a right on the part of such associations to furnish members with legal services. ${ }^{43}$

So far as the automobile club is concerned, it is doubtful whether much comfort can be taken from the Michigan case, as the argument that the association was merely handling individual cases as part of the fulfillment of its own purposes has been advanced in some of the other cases to no avail..4 However, the doctrine of the Thibodeau case may offer a means whereby the motor clubs can spread the costs of minor litigation in connection with automobiles over their entire memberships by agreeing to pay the fees of attorneys to be selected and dealt with by the members individually. There has been statutory authorization of a similar arrangement. In the 1935 Rhode Island act prohibiting unauthorized practice of law, it was expressly provided that the act should not forbid "Any automobile club or association from paying or agreeing to pay for the services of attorney [sic] to advise and defend its members, providing such attorney is of the member's own selection and is not to be subject to the control of said club or association." ${ }^{.5}$ It is possible that such a plan would necessitate the organization of insurance companies, in the light of the Kentucky and Minnesota decisions heretofore considered.

\footnotetext{
${ }^{10}$ Opinions 8 (1925), Am. Bar. Ass'n, Opinions of Conmittee on Professional Ethics and GrievANCES (1936) p. 53 .

1 AM. Bar Ass's, op. cit. stupra note 8, p. 20.

"See Opinion 56 (r93r) (employment by grange association) and Opinion 98 (1933) (employment by state bankers' association to advise member banks), AM. Bar Ass's, op. cit. supra note 40 , at 130 and 194.

'3 People ex rel. Lawyers' Institute of San Diego v. Merchants' Protective Corp., 189 Cal. 531, 209 Pac. 363 (1922); People ex rel. Los Angeles Bar Association v. California Protective Corp., 76 Cal. App. 354, 244 Pac. 1089 (1926); People ex rel. Courtney v. Association of Real Estate Tax-Payers, 354 Ill. 102, 187 N. E. 823 (1933); State ex rel. Physicians' Defense Co. v. Laylin, stupra note 33 (defense of physicians from malpractice suits); Dworken v. Apartment House Owners Association, 38 Ohio App. 265, 176 N. E. 577 (1931); see also (1937) UNaUth. PrAC. News 52 (Report of hearing before Am. Bar. Ass'n committees on Unauthorized Practice and Professional Ethics at which the plan of the Ohio State Medical Association for legal defense of doctors was held to constitute unauthorized practice of law).

Heople ex rel. Chicago Bar Association v. Chicago Motor Club, State ex rel. Seawell v. Carolina Motor Club, both supra note 2.

${ }^{2}$ R. I. Acts 1935 , c. $2190, \$ 46$, Clause $B, q 8$. (No case has arisen in Rhode Island under this section).
} 